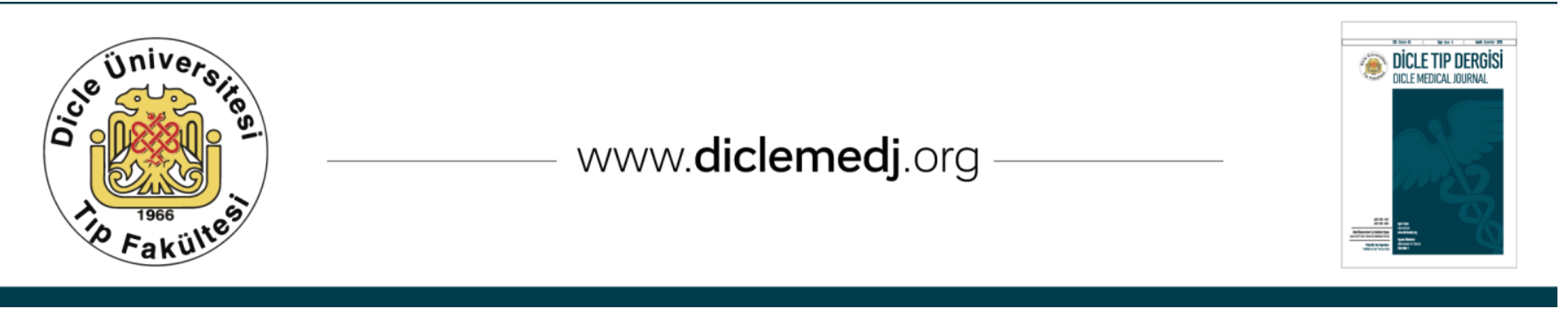

Case Report / Olgu Sunumu

\title{
Metallosis following to neglected failed total knee replacement
}

\author{
Selçuk Frik ${ }^{1}$, Metin Işik² ${ }^{2}$ Bertan Cengiz ${ }^{3}$, Ramin Moradi ${ }^{4}$ \\ 1 Republic of Turkey, Ministry of Health - Mardin State Hospital Orthopedics and Traumatology Clinic, Mardin, Turkey ORCID: 0000-0002-6123-1596 \\ 2 Republic of Turkey, Ministry of Health - Ankara Hospital of Occupational and Environmental Diseases Orthopedics and Traumatology Clinic, Ankara, \\ Turkey ORCID: 0000-0002-0890-6267 \\ 3 Private Koru Sincan Hospital Orthopedics and Traumatology Clinic, Ankara, Turkey ORCID: 0000-0003-1069-3990 \\ 4 Private Koru Sincan Hospital Orthopedics and Traumatology Clinic, Ankara, Turkey ORCID: 0000-0001-7295-9964
}

Received: 16.10.2017; Revised: 19.11.2017; Accepted: 16.05.2018

\section{Abstract}

Patient suffering from pain and color change in her knee 10 years after a total knee replacement diagnosed as metallosis due to failed total knee replacement (TKR).

Beginning: prosthesis fail and implant wearing is a well known and good identified subjects in arthroplasty surgeries. Polyethylene wearing is a common issue but metal wearing and metallosis are rare cases.

Keywords: Metallosis, total knee replacement, pigmentosis.

\section{Aşınmış total diz protezine bağlı ihmal edilmiş metalloz olgusu}

Öz

10 yll önce yapılan total diz protezini takiben ağrı ve ciltte renk değişikliği ile polikliniğe başvuran hastada mevcut protezlerin olağanüstü aşınması sonucu oluşan metalloz bulgusu bildirilmesi amaçlanmıştır.

Anahtar Kelimeler: Metalloz , total diz protezi, pigmentoz.

DOI: 10.5798/dicletip.457272

Yazışma Adresi / Correspondence: Selçuk Frik, T.C. Sağlık Bakanlı̆̆ı Mardin Devlet Hastanesi Ortopedi ve Travmatoloji Kliniği, Mardin, Türkiye email: kozetbey@hotmail.com 


\section{CASE}

A 77 years old lady appeared in the outpatient clinics due the right knee pain following to right (RT) TKR 10 years ago without patellar implant. This was the first clinical visit except the first months of postoperative examinations. The pain was increasing with instability and loss function through the last four years. In the clinical examination there was severe instability and pain and pigmentosis around the distal and of the surgical scar. Blood tests resulted insignificant with normal levels of crp esr and wbc. Direct x-rays acquired at the day of examination and severe wearing of the tibial component and proximal tibia is displayed. Also surrounding radiodensity outlining the suprapatellar and posterior recess of the joint capsule come to attention (picture 1). This radiodensity is the characteristic radiographic finding of metallosis after TKR caused by the presence of embedded metal particles ${ }^{1}$.

At surgery, starting from the dermal tissue all layers was covered with metallic debris. Joint fluid and synovium was black and surrounding tissue was hyperthrophic (picture 2). The tibial polyethylene was worn on the medial side but still attached to the tibial component. The tibial component was made of titanium and severely aroused against chrome-cobalt femoral component. Also wearing was continuing through the medial proximal tibia. Highly dense bone formation on the medial side inspected. Pathological reported as fibrotic and synovial tissues rich in jet-black histiocytes.

Discussion: Metallosis is a complication of failure of total joint procedures due to wearing. Abrasions of metals following to wearing of interposed polyethylene causing large debris of micro metal particles. This condition is generally presented following to total knee arthroplasties including patellar replacement ${ }^{2}$. Particle effect of polyethylene wear is a wellknown issue ${ }^{3}$ in our patient both components seemed to be largely affected. In the literature it was reported metal and polyethylene particles may be carried away from joint replacements by the lymphatic system ${ }^{4}$ with uncertain systemic effects, we couldn't find any lymphadenopathy during the physical examination.

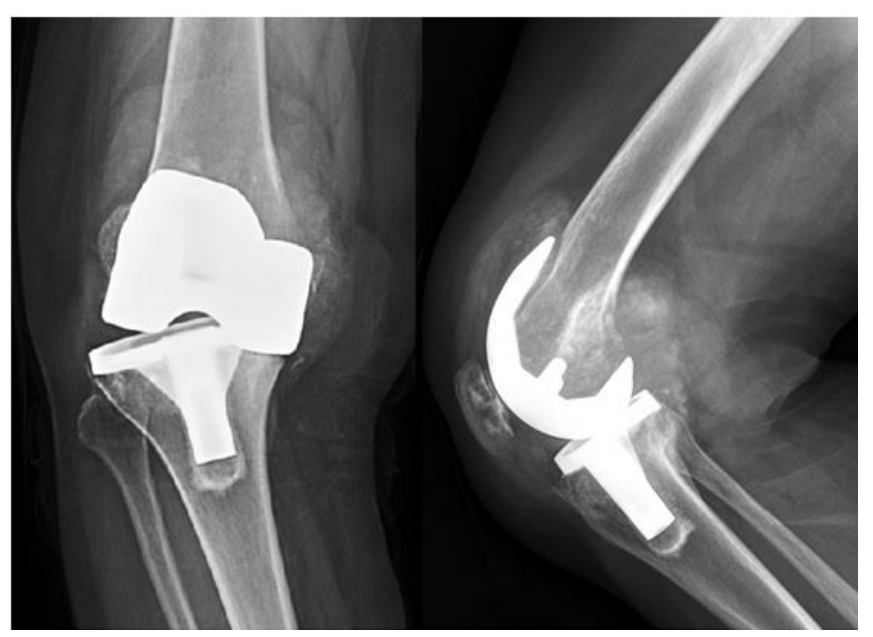

Picture 1: Radiological metallosis sign around the knee

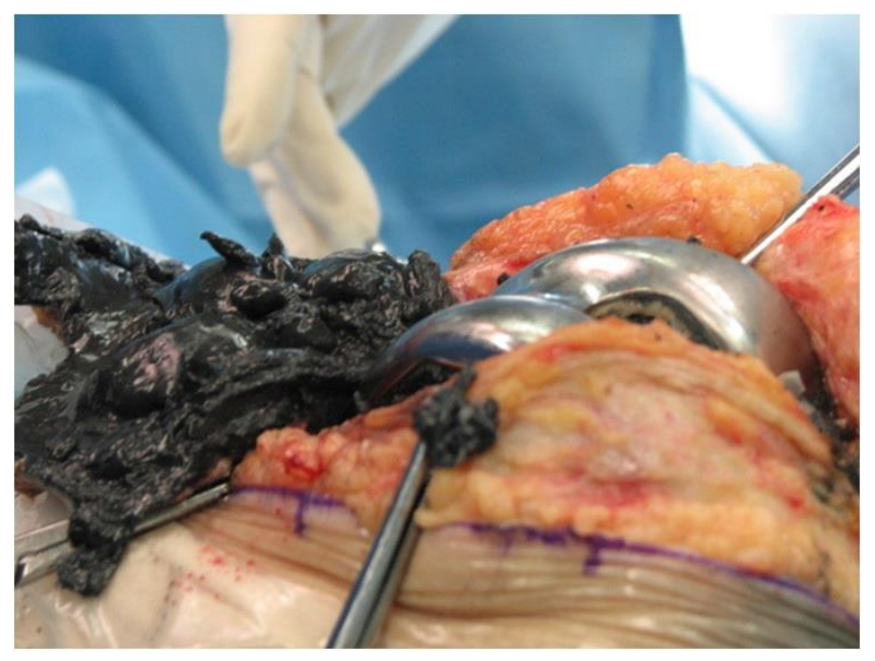

Picture 2: Intraoperative synovial appearance

Declaration of Conflicting Interests: The authors declare that they have no conflict of interest.

Financial Disclosure: No financial support was received. 


\section{REFERENCES}

1. Weissman BN, Scott RD, Brick GW, Radiographic detection of metal-induced synovitisas a complication of arthroplasty of the knee. J Bone Surg Am 1991: 73-A: 1002-7.

2. Rader CP, Lohr H, Whittmann R, Results of total knee arthroplasty with a metalhacked patellar component: a 6-year follow-up study. J Arthroplastv 1996: 11: 92330.
3. Yukihide M, Akio K, Hiroyoshi I, Polyethylene Wear Particles in Synovial Fluid After Total Knee Arthroplasty Clinical Orthopaedics and related research Number 410, pp. 165-72.

4. Shinto $\mathrm{Y}$, Uchida $\mathrm{A}$, Yoshikawa $\mathrm{H}$, et al. Inguinal lymphadenopathy due to metal release from a prosthesis: a case report. J Bone Joint Surg Br1993: 75B: 266-9. 